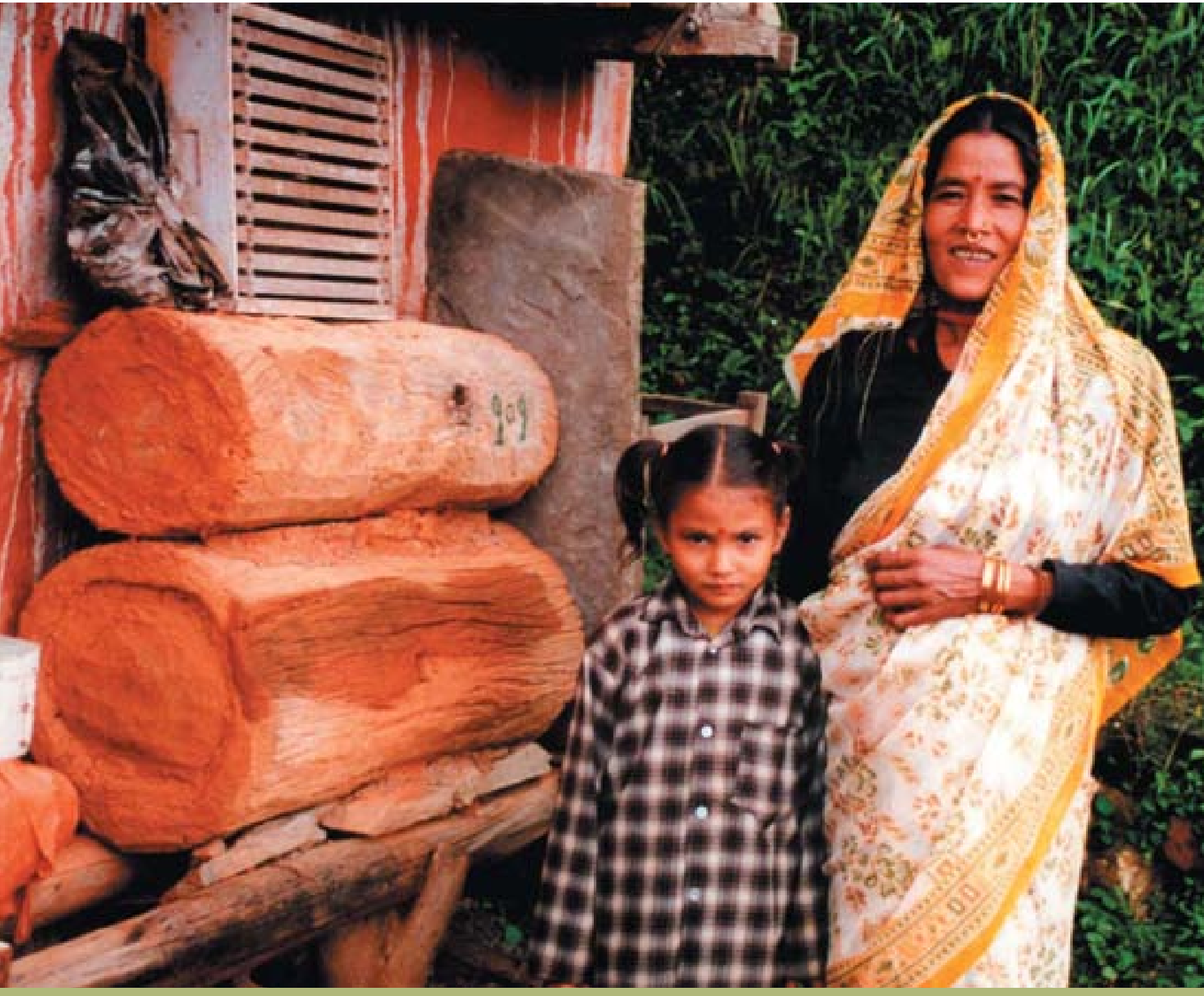

\title{
Beekeeping and Rural Development
}

Farooq Ahmad, Surendra R. Joshi, Min B. Gurung

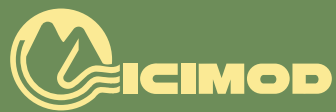




\section{International Centre for Integrated Mountain Development}

The International Centre for Integrated Mountain Development (ICIMOD) is an independent 'Mountain Learning and Knowledge Centre' serving the eight countries of the Hindu Kush-Himalayas Afghanistan, Bangladesh, Bhutan, China, India, Myanmar, Nepal, and Pakistan - and the global mountain community. Founded in 1983, ICIMOD is based in Kathmandu, Nepal, and brings together a partnership of regional member countries, partner institutions, and donors with a commitment for development action to secure a better future for the people and environment of the extended Himalayan region. ICIMOD's activities are supported by its core programme donors: the governments of Austria, Denmark, Germany, Netherlands, Norway, Switzerland, and its regional member countries, along with over thirty project co-financing donors. The primary objective of the Centre is to promote the development of an economically and environmentally sound mountain ecosystem and to improve the living standards of mountain populations.

\section{About the authors}

Farooq Ahmad is the Project Coordinator, Indigenous Honeybees Project, ICIMOD.

Surendra R. Joshi is the Advisor, Sub Sector Promotion, GTZ/Private Sector Promotion Project.

Min B. Gurung is the Institutional Development Officer, Indigenous Honeybees Project, ICIMOD.

\section{Cover photo}

Apis cerana in traditional log hives. Surendra R. Joshi

\section{Copyright (C) 2007}

International Centre for Integrated Mountain Development (ICIMOD)

All rights reserved

\section{Published by}

International Centre for Integrated Mountain Development

Khumaltar, Lalitpur, G.P.O. Box 3226, Kathmandu, Nepal

Telephone: (977 1) 5003222

Fax: (977 1) 5003299

Email: icimod@icimod.org

www.icimod.org

\section{ISBN 9789291150489}

\section{Printed and bound in Nepal by Quality Printers Pvt. Ltd. Kathmandu}

\section{Reproduction}

This publication may be reproduced in whole or in part and in any form for educational or non-profit purposes without special permission from the copyright holder, provided acknowledgement of the source is made. ICIMOD would appreciate receiving a copy of any publication that uses this publication as a source.

No use of this publication may be made for resale or for any other commercial purpose whatsoever without prior permission in writing from ICIMOD.

\section{Note}

The views and interpretations in this publication are those of the author. They are not attributable to ICIMOD and do not imply the expression of any opinion concerning the legal status of any country, territory, city or area of its authorities, or concerning the delimitation of its frontiers or boundaries, or the endorsement of any product. 


\section{Contents}

People, Bees, and Rural Development 5

Promoting Secure and Sustainable Livelihoods through Beekeeping $\quad 7$

$\begin{array}{ll}\text { Physical Security } & 10\end{array}$

$\begin{array}{ll}\text { Conservation of Resources through Bee Diversity } & 12\end{array}$

$\begin{array}{lr}\text { Economic Security } & 14\end{array}$

$\begin{array}{ll}\text { Value Chain for Economic Security } & 22\end{array}$

$\begin{array}{ll}\text { Empowerment } & 26\end{array}$

$\begin{array}{ll}\text { Social Security } & 31\end{array}$

Beekeeping as a Contribution to Improved Rural Livelihoods 32

References and Further Reading $\quad 34$

Some Useful Terms $\quad 35$ 